\title{
Viisikymppisten naisten neuvottelua korkeakoulutuksesta, ikääntymisestä ja työllistettävyydestä
}

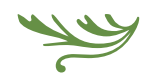

Korkeakoulutus auttaa ikääntyneitä naisia neuvottelemaan asemastaan työmarkkinoilla. Tuore tutkinto antaa myös tunnustuksen työssä hankitulle osaamiselle ja varmistaa muodollisen pätevyyden.

$\mathbf{y}$ KORKEAKOULUTUKSELLA ON VAHVA merkitys asiantuntijastatuksen ja professionaalisen työn määrittelijänä. Koulutus nähdään edelleen yksilön työmarkkina-asemaan myönteisesti vaikuttavana investointina, vaikka työttömyysaste on Suomessa ollut jo pitkään korkea ja myös akateeminen työttömyys on ollut kasvussa. Ilman oikeanlaista tutkintoa uusliberalistisiksi nimetyillä työmarkkinoilla (Miller \& Rose 2008) on vaarassa jäädä työmarkkinakilpailun ulkopuolelle (Brown, Hesketh \& Williams 2003). Kiristyvässä työmarkkinakilpailussa ihannoidaan tehokkuutta: nuoria kannustetaan kouluttau- tumaan mahdollisimman korkealle ja nopeasti, jotta heidän tuottamastaan koulutuspääomasta saataisiin kaikki mahdollinen hyöty irti. Tehokkuuden ja kilpailun korostaminen asettaa keski-ikäisenä korkeakoulututkinnon suorittaneet ristiriitaiseen asemaan suhteessa vallitseviin ihanteisiin. Yhtäältä elinikäistä oppimista edellytetään ja toisaalta myöhemmällä iällä kouluttautuminen näyttäytyy "epätyypillisenä" ja "ei-niin-suotavana" koulutuspolkuna.

Korkeakouluopinnot voivat parantaa työllistettävyyttä vielä yli viisikymppisenäkin (IsopahkalaBouret 2015a; Siivonen \& Isopahkala-Bouret 2016), 
iässä, jolloin aktiivinen työelämään osallistuminen keskimäärin merkittävästi laskee (Eurostat 2015). Tutkinnot eivät kuitenkaan yksin riitä, vaan niin sanotut yksilölliset ja yrittäjämäiset kyvyt, henkilökohtaiset ominaisuudet ja sosiaaliset taidot ovat tulleet yhä tärkeämmiksi työllistettävyyttä määritteleviksi tekijöiksi (Brown, Hesketh \& Williams 2003; Tomlinson 2008). Muodollisen ammatillisen pätevyyden sijaan kysymys onkin huomattavasti monimutkaisemmasta asiasta. Korkeasti koulutettujen ikääntyneiden työntekijöiden voi olla vaikea työllistyä silloinkin, kun työmarkkinoilla on runsaasti kysyntää hyvin koulutetuista työntekijöistä. Ikä itsessään voi nousta erottelevaksi tekijäksi, jos ikääntynyt työntekijä ei vastaakaan ihannetyöntekijän ominaisuuksia.

Tarkastelemme tässä artikkelissa korkeakoulutusta suhteessa ikääntymisen ja työllistettävyyden muuttuneisiin diskursseihin. Kyseessä on tapaustutkimus viisikymppisinä yliopistosta ja ammattikorkeakoulusta ensi kertaa valmistuneiden naisten koulutus- ja työelämäpoluista ja sosiaalisesta asemoitumisesta muuttuvilla työmarkkinoilla. Kysymme artikkelissa: Millaisia merkityksiä viisikymppisenä valmistuneet naiset antavat korkeakoulutukselle suhteessa ikääntymiseen ja vallitsevaan työllistettävyysdiskurssiin? Käymme läpi seuraavaksi tutkimuksen keskeisiä käsitteitä, kuvaamme tutkimusaineiston ja menetelmät. Tämän jälkeen analysoimme aineistoa kolmessa teemallisessa tulosluvussa. Lopuksi esitämme yhteenvedon ja muutamia huomioita analyysimme pohjalta.

\section{TYÖLLISTETTÄVYYS KORKEAKOULUTUKSEN TAVOITTEENA}

Työllistettävyydessä on kyse siitä, omaako henkilö sellaisia kvalifikaatioita, ominaisuuksia, taitoja ja kykyjä, jotka edesauttavat hänen työllistymistään ja työssä pysymistään. Työllistettävyys on kuitenkin eri asia kuin työllisyys tai työllistyvyys. Työllistettävyys mahdollistaa työllistymisen, vaikkakaan se ei sitä välttämättä takaa (Brown, Hesketh \& Williams 2003). Jatkuva itsensä ke- hittäminen ja työllistettävyyden ylläpitämisen vaatimus ulottuu myös niihin, jotka ovat jo työllistyneet. Kiristyvässä työmarkkinakilpailussa työntekijän on todistettava työnantajalleen yhä uudelleen ja uudelleen olevansa työllistettäväksi kelpaava. Työllistettävyydestä onkin muodostunut 1990-luvulta lähtien yksi keskeisimmistä yhteiskuntakelpoisuuden ja kelpo kansalaisuuden määrittelijöistä (Siivonen ym. 2016; Silvennoinen 2007).

Työllistettävyys on myös nostettu yhdeksi Euroopan unionin tärkeimmäksi korkeakoulupoliittiseksi tavoitteeksi (Puhakka, Rautopuro, Tuominen \& Vuorinen-Lampila 2012). Vallitseva diskurssi uudelleen määrittelee uusliberalistisen koulutuspolitiikan hengessä korkeakoulutuksen tuottamat tiedot ja taidot työllistettävyydeksi (Boden \& Nedeva 2010). Tämä heijastelee korkeakoulutuksella saavutettavia lyhyen aikavälin hyötyjä. Koulutus nähdään ensisijaisesti taloudellisena investointina, ja korkeakoulutuksen pääasialliseksi tavoitteeksi on muodostunut sopivan työvoiman tuottaminen työmarkkinoiden tarpeisiin. Tämän seurauksena sellaiset perinteiset tehtävät kuin kulttuuriperinnön välittäminen, uusien näkökulmien esittäminen ja kriittinen yhteiskunnallinen ajattelu on sysätty taka-alalle (Puhakka, Rautopuro \& Tuominen 2010).

Työllistettävyysdiskurssi rajaa korkeakoulutuksen tavoitteeksi yksilön näkökulmasta henkilökohtaisen työmarkkina-aseman parantamisen. Arvostettu tutkinto yliopistosta tai korkeakoulusta tarjoaa todennäköisesti etulyöntiaseman työnhakutilanteessa. Saman tasoisen tutkinnon omaavien kilpailussa vaikuttavat kuitenkin tutkinnon, opiskelumenestyksen ja opiskelupaikan maineen lisäksi myös muun muassa työkokemuksen kautta kertynyt osaaminen ja henkilökohtaiset ominaisuudet (Tomlinson 2008; Siivonen \& Isopahkala-Bouret 2016; Ojala \& Isopahkala-Bouret 2015). Rinne (1998) kutsuu tätä ilmiötä takiaispallostrategiaksi: yksilön tulisi takiaispallojen tavoin tartuttaa itseensä vaikutteita, tulkintoja, käyttäytymiskoodeja ja sosiaalisia kontakteja. Menestyksellinen takiaispallo vaeltaa elämänsä keräten erilaisia koulutus- ja muita kokemuksia, jotka vahvistavat hänen työllistettävyyttään. 
Kilpailua parhaista työpaikoista ei kuitenkaan käydä vain yksilöiden kesken, vaan myös erilaisten sosiaalisten ryhmien välillä (Brown, Hesketh \& Williams 2003). Työllistettävyyden käsite itsessään suuntaa katseen yksilöön, mutta työllistettävyyttä tulisi tarkastella yksilöä laajemmin erilaisten työmarkkina-asemien välisten jännitteiden kautta (ks. positional conflict theory; Brown, Hesketh \& Williams 2003). Työntekijöiden keskinäistä kilpailua säätelee työmarkkinoiden kysynnän ja tarjonnan lisäksi myös koulutusinstituutioiden välinen kilpailu sekä yksilön arvottaminen tietyn ryhmän edustajana sosiaalisen ja kulttuurisen pääoman mukaan (Brown, Hesketh \& Williams 2003). Yhteiskunnalliset erot, kuten sukupuoli, yhteiskuntaluokka, etnisyys sekä ikä, johon tässä artikkelissa erityisesti keskitytään, määrittelevät sitä kuinka yksittäinen työnhakija asemoituu työmarkkinoilla suhteessa muihin työnhakijoihin. Ikääntyminen mielletään ominaisuudeksi, joka pikemminkin heikentää kuin parantaa työllistettävyyttä (esim. Irni 2010; Jyrkinen \& McKie 2012).

\section{IKÄÄNTYVÄT NAISET TYÖMARKKINOILLA}

Työvoiman ikääntymisestä ja ikääntyneiden työllistettävyydestä on käyty Suomessa runsaasti keskustelua koko 2000-luvun ajan, joskaan korkeakoulutuksen merkitystä ei ole juurikaan huomioitu tässä keskustelussa. Aikaisempi tutkimus on nostanut esiin useita ikääntyneiden työllistettävyyttä vaikeuttavia tekijöitä. Euroopassa osallistuminen työelämään laskee merkittävästi 55 ikävuoden jälkeen ja tämä koskee erityisesti naisia (Eurostat 2015). Yli 50 prosenttia eurooppalaisista 55-64-vuotiaista naisista on työelämän ulkopuolella (Eurostat 2015). Eri maiden poliittiset sekä sosiaaliset ja kulttuuriset tekijät selittävät sitä, miksi vain harvat tässä ikäryhmässä ovat aktiivisesti mukana työelämässä.

Suomessa sosiaali- ja terveyspalvelut sekä yleinen asenneilmapiiri suosivat naisten työssä käymistä kodin ulkopuolella ja keski-ikäisten naisten aktiivinen osallistuminen työelämään on korkeampi kuin monissa muissa Euroopan maassa. Suomalaisista 55-65-vuotiaista naisista vielä yli 65 prosenttia on aktiivisesti työelämässä mukana (Eurostat 2015). Kuitenkin myös Suomessa ikääntyneet työntekijät kohtaavat ennakkoluuloja ja suoranaista ikäsyrjintää työpaikoilla. Niina Viitasalo (2015) osoitti väitöstutkimuksessaan, että yli 55-vuotiaat naiset olivat yleisimmin kokeneet ikäsyrjintää työssään. Jopa 7,5 prosenttia heistä oli kokenut ikäsyrjintää ja useimmiten tämä tapahtui rekrytointitilanteessa (Viitasalo 2013). Pitkiä työuria kuitenkin tuetaan ja ikääntyneitä otetaan töihin, jos se on työnantajan kannalta strategisesti järkevää eli jos taloudellinen tilanne, henkilöstön ja asiakaskunnan ikärakenne sekä mahdollinen työvoimapula sitä puoltavat (Pärnänen 2011).

Tuoreita tutkintoja sekä nuoruuteen liitettyjä ominaisuuksia, kuten uuden oppimisen nopeutta, korostetaan nykyajan työelämässä enemmän kuin iän tuomaa kokemusta (Ruoholinna 2009). Ikääntyvien korkeakoulutettujen työelämään osallistuminen on kuitenkin kolme kertaa todennäköisempää kuin heikommin koulutettujen (Eurostat 2015). Nämä tilastot viittaavat siihen, että he, joilla on korkeakoulututkinto tai jotka ovat asiantuntija- tai johtotehtävissä pysyvät todennäköisemmin työelämässä, koska he ovat vähemmän alttiita ikäsyrjintään työpaikallaan (Irni 2010; Moore 2003).

Yhteiskunnalliset eronteot suhteessa esimerkiksi ikään, sukupuoleen, yhteiskuntaluokkaan ja koulutustaustaan, määrittelevät sosiaalista asemoitumista suhteessa työllistettävyysdiskurssiin. Ikääntymiseen liittyvät merkityksenannot ovat kuitenkin tilanteisia, eivätkä ne automaattisesti heikennä tai vahvista käsitystä henkilön työllistettävyydestä. Ikä kietoutuu yhteen monimutkaisella tavalla muiden yhteiskunnallisten erojen, kuten koulutustaustan ja sukupuolen, kanssa ja ne rakentavat yhdessä ikääntyvien työntekijöiden suhteellista asemaa ja mahdollisuuksia työelämässä (Irni 2010; Siivonen \& Isopahkala-Bouret 2016). Korkeasti koulutetut ja asiantuntijatehtävissä toimivat naiset ovat lähtökohtaisesti hyvässä sosiaalisessa asemassa, mikä tulee huomioida ikääntymistä ja työllistettävyyttä tarkasteltaessa.

\section{TUTKIMUKSEN TOTEUTUS}

Tämän tapaustutkimuksen aineistona olivat kahden viisikymppisen naisen narratiiviset, työ- ja koulutuselämäkerralliset haastattelut (Hyvärinen \& Löyttyniemi 2005). Haastattelut tuotettiin osana kahta laajempaa tutkimusta, joissa tarkasteltiin yhteensä 24 aikuisopiskelijan toisen asteen jälkeisiä koulutus- ja 
työelämäpolkuja (ks. loppuviite 1 ja 2). Haastattelutilanteissa pyrimme antamaan tilaa haastateltavien omalle kerronnalle ja heidän oppimiseen, koulutukseen ja työelämään kiinnittyville merkityksenannoilleen. Haastattelut nauhoitettiin ja litteroitiin sanatarkasti myöhempää analyysia varten.

Molempien tutkimusprojektien haastattelut toteutettiin vuonna 2012. Tutkimushankkeiden alkuperäiset ongelmanasettelut ja haastatteluteemat poikkesivat toisistaan, mutta molemmissa hankkeissa tuotettuja haastatteluaineistoja yhdistivät elinikäisen oppimisen, aikuisena opiskelun ja iän/ikääntymisen teemat. Hankkeita yhdisti myös koulutuksen ja työn suhteen tarkastelu aikuisopiskelijoiden näkökulmasta. Olemme analysoineet tutkimusprojektien haastatteluja yhdessä aikaisemminkin (Siivonen \& Isopahkala-Bouret 2016).

Tähän tutkimukseen valittiin mukaan kahden naisen haastattelut koulutuselämäkerrallisen samankaltaisuuden perusteella. Marjaana valikoitui mukaan Isopahkala-Bouretin haastatteluaineistosta ja Kaarina Siivosen aineistosta (haastateltavien nimet ovat pseudonyymejä). Parin yhdistävinä tekijöinä ovat sukupuoli, ikä, koulutushistorian vaiheet, korkeakoulututkinto viisikymppisenä ja asema työelämässä (ks. taulukko 1). Apuna tapauksen rajaamisessa käytettiin Cromptonin (2001) vertailevan laadullisen tapaustutkimuksen tarpeisiin kehittelemää biographical matching menetelmää, jota myös Jyrkinen ja McKie (2012) ovat soveltaneet työurien, sukupuolen ja iän intersektionaaliseen analyysiin. Menetelmän avulla on mahdollista muodostaa haastateltavista pari, jota tarkastellaan yhtenä tapauksena. Biographical matching -menetelmä mahdollistaisi myös vertailevan tutkimusasetelman hyödyntämisen eli esimerkiksi maakohtaisten, alueellisten tai alakohtaisten erojen tarkastelun, edellyttäen, että haastateltavat edustaisivat erilaisia ympäristöjä. Tässä tapauksessa naiset ovat kuitenkin molemmat Suomesta, pääkaupunkiseudulta ja ainoa selkeä kontekstuaalinen ero heidän koulutus- ja työhistorioissaan on korkeakouluinstituutioiden välinen ero: yliopisto (Marjaana) versus ammattikorkeakoulu (Kaarina). Analyysissamme keskitymme siis yhtenäisen tapauksen analyysiin, korostaen naisten kertomusten samankaltaisuutta, emmekä pyri vertailevaan tutkimukseen.

Analysoimme haastatteluaineistoa narratiivis-diskursiivisesti (Davies \& Harre 1990; Siivonen 2016; Mutanen \& Siivonen 2016) ja tarkastelemme, miten korkeakoulutuksen merkitys kietoutuu ikääntymiseen ja työllistettävyyteen viisikymppisenä korkeakoulututkinnon ensi kertaa suorittaneiden Marjaanan ja Kaarinan kerronnassa. Olemme kiinnostuneita merkitysten diskursiivisesta rakentumisesta, siitä, miten erilaisista merkityksistä neuvotellaan ja miten haastattelemamme naiset asemoituvat vallalla oleviin diskursseihin koulutuksensa, ikänsä ja työmarkkinaasemansa suhteen.

\begin{tabular}{|c|c|c|}
\hline & MARJAANA & KAARINA \\
\hline Ikä (2012) & $55 \mathrm{v}$. & $56 \mathrm{v}$. \\
\hline Koulutushistoria & $\begin{array}{l}\text { talouskoulu, } \\
\text { aikuislukio, } \\
\text { yo-pohjainen ammatillinen tutkinto, } \\
\text { johdon eMBA -tutkinto }\end{array}$ & $\begin{array}{l}\text { talouskoulu, } \\
\text { ammatillinen tutkinto, } \\
\text { aikuislukio, } \\
\text { johtamisen erityisammattitutkinto }\end{array}$ \\
\hline $\begin{array}{l}\text { Korkeakoulu- } \\
\text { tutkinto }\end{array}$ & kauppatieteiden kandidaatin ja maisterin tutkinto & restonomin ammattikorkeakoulututkinto \\
\hline Työhistoria & $\begin{array}{l}\text { Ollut mukana työelämässä 16-vuotiaasta lähtien } \\
\text { ja tehnyt pitkän uran ravintola ja catering -alalla. } \\
\text { Työskennellyt esimiestehtävissä ensimmäistä kertaa } \\
\text { 24-vuotiaana. Kokemusta myös useista kouluttajan } \\
\text { ja päällikön tehtävistä. Valmistumisen aikoihin } \\
\text { vaihtoi ison organisaation johtotehtäviin uudelle } \\
\text { alalle, pois ravintola ja catering -alalta. }\end{array}$ & $\begin{array}{l}\text { Työskennellyt samassa organisaatiossa } \\
\text { puhtaanapitoalalla nuoruudesta lähtien. } \\
\text { Toiminut esimiestehtävissä useita vuosia. } \\
\text { Eteni korkeakoulututkinnon suoritettuaan } \\
\text { asiantuntijatehtäviin samassa organisaatiossa ja } \\
\text { samalla alalla. }\end{array}$ \\
\hline
\end{tabular}

Taulukko 1. Elämäkerrallisen samankaltaisuuden perusteella muodostettu pari. 


\section{YKSITYISELL ̈̈ SEKTORILLA}

\section{VOIDAAN JOUSTAVAMMIN}

\section{TUNNISTAA TYÖKOKEMUKSEN}

KAUTTA HANKITTUA

OSAAMISTA.

diskursseihin mahdollisti myös samanlaisten kerronnallisten resurssien (Mutanen \& Siivonen 2016) käyttämisen. Seuraavassa analysoimme, miten Marjaana ja Kaarina tulkitsivat korkeakoulutuksen merkitystä suhteessa työllistettävyyteen kokeneina ja hyvin koulutettuina, mutta samalla myös ikääntyvinä työntekijöinä.

\section{KORKEAKOULUTUTKINTO VARMISTAA MUODOLLISEN PÄTEVYYDEN}

Ikääntyminen kietoutuu aineistossamme sukupuoleen; ikääntyvien miesten ja naisten sosiaalinen positio rakentuu työelämässä eri tavoin johtuen erilaisista ikäsidonnaisista diskursiivisista odotuksista (Isopahkala-Bouret 2016). Viisikymppisenä korkeakoulututkinnon suorittaneet naiset käyvät myös erilaisia neuvotteluja omasta työllistettävyydestään verrattuna nuoriin korkeakoulutettuihin naisiin (IsopahkalaBouret 2016). Ikä ja sukupuoli eivät kuitenkaan määrity abstrakteina tai staattisina positioina, vaan elettyinä sosiaalisina suhteina, joihin sisältyy jännitteitä ja neuvottelua (Ojala 2010; Siivonen 2012). Sosiaaliset erot materialisoituvat eri tavoin arvostettuina sosiaalisina, kulttuurisina ja taloudellisina resursseina, jotka puolestaan asettavat yksilöt hierarkkisesti rakentuviin kategorioihin (Skeggs 1997).

Narratiivis-diskursiivinen tutkimusote mahdollistaa korkeakoulutuksen ja työllistettävyysdiskurssin kriittisen tarkastelun sekä ikääntymiseen liittyvien sosiaalisten erojen näkyväksi tekemisen. Samalla ikääntymiseen kietoutuvia toiseuttavia diskursseja ja merkityksiä on mahdollistaa haastaa ja uudelleen määritellä vastakertomusten kautta (Andrews 2004; Phoenix \& Smith 2011; Isopahkala-Bouret 2015a: 2016). Diskurssit toimivat ikään kuin kulttuurisina meta-narratiiveina (Gullette 2003) säädellen sitä, miten keski-ikäisten naisten on mahdollista puhua koulutus- ja työhistoriastaan. Vastakertomukset nimensä mukaisesti vastustavat vallitsevien odotusten mukaisia sosiaalisia positioita ja pyrkivät laajentamaan toimijuuden mahdollisuuksia.

Analysoimme erityisesti kerrontaa, jossa tapauksemme naiset puhuivat samankaltaisista koulutusja työpoluistaan. Samankaltainen paikantuminen suhteessa korkeakoulutuksen ja työllistettävyyden

Yksi suurimmista syistä suorittaa korkeakoulututkinto keski-iässä on työelämässä vaadittavien koulutuskvalifikaatiovaatimusten nousu (Isopahkala-Bouret 2015b). Koulutusinflaation eli koulutuksen suhteellisen arvon alenemisen myötä 1970-luvulla ja 1980-luvun alussa hyvän alun työuralle tarjonneet tutkinnot eivät usein ole enää kilpailukykyisiä muuttuneilla työmarkkinoilla (Aro 2014). Edes työtehtävien vaihtaminen saman organisaation sisällä, nykyisiä työtehtäviä vastaaviin tehtäviin ei ole välttämättä mahdollista ilman päivitettyä tutkintoa. Työkokemuksesta huolimatta ikääntyvien työntekijöiden koulutusta arvioidaan monesti työnhakutilanteessa samoilla kriteereillä kuin nuorempien. Muodollisten koulutusvaatimusten merkitys työllistettävyyden edellytyksenä korostuu erityisesti julkisella sektorilla. Yksityisellä sektorilla voidaan joustavammin tunnistaa ja tunnustaa myös epämuodollisen oppimisen ja työkokemuksen kautta hankittua osaamista.

Tämän tutkimuksen tapauksessa molemmat naiset olivat aloittaneet työelämässä jo nuorena ja suorittaneet suhteellisen lyhytkestoisen ammatillisen koulutuksen. Molemmat olivat aluksi käyneet talouskoulun ja jatkaneet opintojaan suorittaen aikuislukion ja ammatillisen toisen asteen tutkinnon. Molempien koulutus- ja työelämäpolku painottui naisvaltaisille kahvila-, ravintola- ja puhtaanapitoaloille. Molemmat olivat edenneet vastuullisiin esimiestehtäviin luontevasti uusien työtehtävien myötä. Molemmat olivat myös suorittaneet johtamistehtävien tueksi, täydennyskoulutuksena, erilaisia lyhytkestoisia kursseja sekä pitkäkestoisemman johtamisen erityisammattitutkinnon (Kaarina) ja johdon Executive Master of Business and Administration (eMBA) -tutkinnon (Marjaana).

Molemmat naiset olivat kuitenkin myös törmänneet siihen, että aikaisemmin hankittu koulutus ja 
työkokemuksen kautta kertynyt osaaminen eivät taanneet pätevyyttä asiantuntijatehtäviin, vaan vasta korkeakoulututkinto formalisoi oman osaamisen ja takasi muodollisen pätevyyden:

"Ja sitt ... se tutkintopaperi siihen ihan ... ku tuli tää haku, niin siin oli niin ku tää pätevyysvaatimuskysymys... Taas sen kanss meill on aika tarkkaa, ... jos se on määritelty se tehtävä sitt tähän AMK-tasoseks, niin se on siinä ja sillon oli hyvä se tutkinto... tää oli se niin ku se pätevyysvaatimus. Eli en mä ois vanhall tutkinnoll. Niin. Vanhall tutkinnolla mä en olis ees päässy siihen." (Kaarina)

"Vaikka mä oon tietysti saanu koulutusta niissä työpaikoissa [joissa olen ollut], mutt mä oon halunnu niinku muodollisen jonkunlaisen pätevyyden ja osaamisen sinne [sen lisäksi]." (Marjaana)

Kaarinalle tärkeä syy lähteä opiskelemaan korkeakouluun oli se, että hän halusi päivittää tutkintonsa vastaamaan nykypäivän työmarkkinoiden vaatimuksia. Ammattikorkeakoulututkinto toi hänelle muodollisen pätevyyden ja mahdollisuuden hakea asiantuntijatehtäviin omassa organisaatiossaan. Myös Marjaana toi esille sen, että ammatillisen osaamisen kehittymisen lisäksi hän haki myös tutkinto-orientoituneen opiskelun kautta muodollista osoitusta pätevyydestään. Viimeisimpään johtotason tehtävään Marjaana oli vaihtanut siinä vaiheessa, kun hänellä oli jo valmiina alempi korkeakoulututkinto ja hän oli suorittamassa maisteriopintoja loppusuoralla.

"Ei, sitä [maisterin tutkintoa] ei vaadittu... Kyllä toin [esiin, että oon opiskelemassa] ja se oli mulla, siis mulla näky, että tietty määrä mulla on opintopisteitä kasassa, ja... ja sitte tuota niin mä kerroin selkeesti mun tavotteeni [valmistua]." (Marjaana)

Marjaana toi haastattelussa esiin, että ylempää tutkintoa ei missään vaiheessa suoraan häneltä työnhakuprosessin aikana vaadittu. Kuitenkin tulkitsemme, että aikuisopiskelu ja loppusuoralla olleet opinnot määrittivät Marjaanan työllistettäväksi. Hän korosti itsekin puheessaan sitä, että nykyään koulutusvaatimukset ovat nousseet. Oli poikkeuksellista, jos hänen alallaan asiantuntijatehtäviin palkattiin henkilö, jolla ei ollut maisteritasoista tutkintoa. Myös Kaarina toi esiin tarpeen päivittää tutkintonsa vastaamaan nykyisten työmarkkinoiden tasoa sekä nuorempien työntekijöiden koulutustasoa.

"Mä aattelin [lähteä suorittamaan] tota ammattikorkeekoulututkintoo, koska, sen takia, että kun kuitenki meiänki alalla, niin, niin tutkinnot on, ja joka alalla tutkinnot niin ku kehittyy. Ja mull on [alan ammatillinen] tutkinto, mutt kyll ne alkaa olla jo aika vanhoja tutkintoja... Ja se oli vähän semmonen, ett eipähän tuu sitte nää, sanottasko nyt näin, että ettei tulis sitten sii, nää nuoremmat tutkinnon suorittajat sanomaan, ett sull on vanhat tiedot. [nauraa]. Ett se oli vähän tämmönen, ett aatteli, ett ei tuu sitt kukaan sanomaan, ett ei sullakaan niitä päivitettyi tietoja oo." (Kaarina)

"Onhan se siis sillä tavalla, että eihän täällä oo... täällähän on, mun [asiantuntijatehtävissä toimivat] alaiseniki on suurin osa akateemisia [eli yliopistotutkinnon suorittaneita]. Että onhan se riski ottaa ei-akateeminen [töihin asiantuntijatehtäviin]." (Marjaana)

Marjaanan ja Kaarinan haastatteluista voidaan tulkita, että vanhempien ja nuorempien työntekijöiden välinen koulutustason ero synnytti jännitteitä työpaikalla, vaikka molemmat naiset olivat sinänsä hyvissä asemissa. Tuore korkeakoulututkinto varmisti, että haastattelemamme naiset olivat samalla viivalla nuorempien työnhakijoiden kanssa työnhakutilanteessa ja että oma koulutustaso vastasi omaan organisaatioon saman tasoisiin tehtäviin palkattujen nuorempien työntekijöiden koulutusta.

Suomalaisten yleinen koulutustason nousu on Mikko Aron mukaan (2014) johtanut siihen, että vanhempien työntekijöiden koulutusta verrataan tai he vertaavat itse itseään suhteessa nuorempien koulutustasoon. Työllistettävyysdiskurssi ja koulutustasoa koskeva vaade koskettaa kaikkia työntekijöitä; se ei rajoitu vain työnhakutilanteeseen tai työmarkkinoiden ulkopuolella oleviin ikääntyviin työnhakijoihin.

Korkeakoulututkinto toimii ikääntyvien työntekijöiden valttikorttina työllistettävyyteen ja ikään liittyvissä neuvotteluissa suhteessa nuorempiin työntekijöihin. On vaikeampi kyseenalaistaa ikääntyneen työntekijän osaamista, kun siitä on myös muodollista 
näyttöä, kuten Kaarina edellä totesi. Tuoreen korkeakoulututkinnon hankkimalla epäsuhta asiantuntija-aseman ja koulutustason välillä poistuu, vaikka mikään muu ei sinänsä muuttuisikaan (IsopahkalaBouret 2015b). Myös kouluttautuminen aikuisiällä työn ohessa on itsessään työllistettävyyttä parantava tekijä (Siivonen \& Isopahkala-Bouret 2016).

\section{JÄNNITTEET MUODOLLISEN KOULUTUKSEN JA KOKEMUKSEN KAUTTA HANKITUN OSAAMISEN VÄLILLÄ}

Samalla kun nuorempien työntekijöiden tuoreet (ja korkeammat) tutkinnot asettivat vanhan tutkinnon omaavat ikääntyvät työntekijät epäsuotuisaan asemaan, myös muodollinen ja epämuodollinen osaaminen asettuivat hierarkkiseen suhteeseen (Ruoholinna 2009). Marjaanan ja Kaarinan kerronnassa tutkinnoilla osoitettavissa oleva osaaminen näyttäytyi merkityksellisemmältä silloinkin, kun sille ei ollut perusteita.

"Kyll mä nyt koen, ett sitä osaamista, mitä mulla on, niin sitä arvostetaan. Ja ainakin mun lähiesimies sitä arvostaa ja moni muu, mutta... Vähän siellä ehkä, vähän siellä ehkä niin ku tuijotetaan kylläkin tutkintoi, ihan siihen tutkinnon suo, suoritus, ett siihen, ett sull on se muodollinen pätevyys." (Kaarina)

"Joskus se [että tutkinnoilla on väliä] heijastuu akateemisena sievistelynä. [naurahtaa...] se heijastuu sillä tavalla, että mennään sen pätevyyden taakse, ett 'minä olen [tän alan] maisteri, että muistakaa nyt'. Vaan että... vaan jos se osaaminen onkin niinkun, se on matkan varrella löystynyt, se on vahentunu, ni sitä ei niinkun hyväksytä, että sitä pitäisi päivittää sitä osaamista, vaan mennää sen pätevyyden taakse. Joka minun mielestä ei ole oikein. (Marjaana)

Kaarina oli kokenut, että hänen kokemustaan ja käytännön osaamistaan kyllä arvostettiin organisaatiossa, jossa hän työskenteli. Kuitenkin hän arvioi, että tutkintoja arvostettiin enemmän kuin työkokemusta ja niihin "tuijotettiin". Marjaana tunnisti saman ilmiön, eikä omasta taustastaan johtuen halunnut sellais- ta hyväksyä. Hän kutsui tutkintojen ylikorostamista "akateemiseksi sievistelyksi".

Marjaanalla ja Kaarinalla oli molemmilla ammatillinen koulutus, jonka pohjalle he olivat rakentaneet pitkän työkokemuksensa ja aikuisopintonsa. He olivat saavuttaneet työurallaan jo paljon ennen kuin heistä korkeakoulututkinnon myöstä tuli muodollisesti päteviä nykyisiin asiantuntijatehtäviin. He eivät tietoisesti tehneet numeroa oman koulutuksellisen asemansa noususta valmistumisensa jälkeen, sillä silloin he olisivat tulleet samalla mitätöineeksi oman aikaisemman asemansa ja arvottaneeksi kaikki "eikorkeakoulutetut" alempiarvoisiksi.

"Sillä [ei] oo mulle sillä tavalla merkitystä. [.. ] en mä sitä täällä toitota tai niinku tehny siitä hirveetä tämmöstä hulabaloota, koska se on kuitenkin tää sama ihminen, joka tänne on palkattu. Ja... ja mä niinku persoonana teen sitä työtä. Se, että mull on se muodollinen pätevyys, niin ei se tee mua sen niinku kummemmaksi kuitenkaan." (Marjaana)

Marjaanan viittaus siihen, että hän on edelleen "sama ihminen" voidaan tässä yhteydessä tulkita suhteessa koulutuksen kautta saavutettavaan sosiaaliseen asemaan. Sen voi tulkita vastapuheena oletukselle siitä, että korkeakoulutuksella tavoitellaan ensisijaisesti sosiaalista nousua ja yhteiskunnallisen aseman parantumista. Korostamalla, että on edelleen sama persoona kuin ennen valmistumista on Marjaanalta ennen kaikkea vahva kannanotto siihen, että hän ei halua aliarvioida omaa taustaansa. Jatkuvuuden korostaminen (Linde 1993) ja korkeakoulutuksen kautta savutettujen hyötyjen ja uralla etenemisen vähättely ("ei tee kummemmaksi kuitenkaan") voidaan nähdä kerronnallisina keinoina, jotka vahvistavat omaelämänkerrallista jatkuvuutta ja samalla ylläpitävät oman koulutus- ja työhistorian arvoa. Marjaana ei myöskään halunnut omalla toiminnallaan korostaa koulutustaustasta johtuvia yhteiskunnallisia erontekoja.

Kaarina puolestaan korosti korkeakoulututkinnon sijaan aikuislukion merkitystä itselleen:

"Ja, tota, ja, ja se [aikuislukio] on kaikist opinnoista edelleen, kaikist opinnoist se on edelleen paras. Mutt 
se on niin henkilökohtanen, mä oon tehny sen vaan niin kun jotenki itelleni." (Kaarina)

Työväenluokkaisesta taustasta tulevalle Kaarinalle aikuislukion ja ylioppilastututkinnon suorittaminen menestyksekkäästi osoitti, että hän ei olekaan ”huono" oppilas ja "miinus-tyttö", jollaiseksi hän positioitui nuorena peruskoulussa (Siivonen 2016). Aikuislukio oli hänelle henkilökohtaisesti tärkeä ja osoitti, että hän oppii "normaalisti". Aikuislukion merkitys ei rakentunut työllistettävyydestä käsin, mutta lukio-opinnot toimivat kuitenkin ponnahduslautana jatko-opinnoille ammattikorkeakoulussa, joka puolestaan legitimoi muodollisen pätevyyden asiantuntijatehtäviin.

Marjaana toki ilmaisi myös, että hän oli ylpeä ja tyytyväinen siihen, että oli onnistunut viemään opintonsa päätökseen, vaikka hänkään ei omien sanojensa mukaan ollut ollut mikään luokkansa paras oppilas. Samalla hän tiesi, että kaikki eivät pysty suorittamaan aikuisopintoja ja korkeakoulututkintoa, vaikka haluaisivatkin.

"Kaikki mun alaisenikaan eivät tiedä, ett mä olen valmistunu. Mä en oo siitä tehny hirveetä numeroa. Koska sill ei oo mun mielestä merkitystä. Ja mä tiedän, ett se satuttaa joitakin ihmisiä sillä tavalla, ett he kokee niinku semmosena... alemmuudentunteita hyvin helposti. Ja se on turha korostaa sellaista, millä tietää niinku ihmisten... ett se ei... se ei auta heidän tilannettaan." (Marjaana)

Vaikka Marjaana ja Kaarina olivat onnistuneet päivittämään tutkintonsa, he tiesivät, että kaikilla ikääntyvillä työntekijöillä ei syystä tai toisesta ole siihen mahdollisuutta. Työllistettävyyden parantamisesta omaa koulutustasoa nostamalla tulee helposti imperatiivi, joka heikentää entisestään vähemmän koulutettujen ikääntyvien työntekijöiden asemaa työmarkkinoilla. Marjaana ja Kaarina eivät siksi itse halunneet korostaa tutkintojen merkitystä sosiaalisen aseman määrittelijöinä.

\section{YKSILÖLLISTEN KYKYJEN JA OMINAISUUKSIEN KOROSTAMINEN OSANA IKÄNEUVOTTELUA}

Pitkästä työkokemuksesta ja tuoreista korkeakouluopinnoista huolimatta, on mahdollista kokea työl- listyminen vaikeaksi täytettyään 55 vuotta. Vaikka nuorempana työllistyminen olisi ollut helppoa, ei tietyn iän ylittäneitä enää välttämättä kutsutakaan haastatteluihin (Siivonen \& Isopahkala-Bouret 2016). Huolimatta siitä, että Suomessa eläkeikää on joustavasti nostettu aina 68 ikävuoteen saakka, on Eeva-Leena Vaahtio (2003) suomalaisten työnantajien rekrytointikäytäntöjä tutkiessaan tullut siihen johtopäätökseen, että paras työmarkkinaikä päättyy 55-vuotiaana. Tämän jälkeen työllistettävyys ja työnsaannin mahdollisuus laskee merkittävästi. Myös Niina Viitasalo $(2013 ; 2015)$ on tuonut esiin erityisesti 55 vuotta täyttäneisiin naisiin kohdistuvan ikäsyrjinnän.

Kaarina ja Marjaana eivät kertoneet kohdanneensa suoranaisia ikään liittyviä ennakkoluuloja tai syrjintää. Kaarina kyllä toi esiin epävarmuuteensa rekrytointitilanteeseen liittyen pyrkiessään omassa organisaatiossaan ammattikorkeakoulutusta edellyttäviin johtotehtäviin:

"Mä sanoin mun esimiehelle, ett mä oon oikeesti hämmästyny [siitä, että minut valittiin] ... niin hän sano, ett niin ku miten sä voit olla hämmästyny, että täähän oli ihan selvä asia. ... kenellä, kenellä olisi, niin ku kenellä olisi se laajempi tuntemus niin ku valmiiks jo näistä asioista. Mä sanoin, ett mä luulin, että se on se este tälle jo, niin hän sano, ett no, ei tietenkään oo." (Kaarina)

Kaarinan epävarmuus omasta mahdollisuudestaan tulla valituksi tehtävään saattaa heijastella ikään ja sukupuoleen liittyvää huolta omasta työllistettävyydestään huolimatta työkokemuksen kerryttämästä osaamisesta ja tuoreen ammattikorkeakoulututkinnon tuomasta muodollisesta pätevyydestä. Kaarina pohtii valintaansa:

"Varmaan [mut valittiin tähän tehtävään] sen takia, että, että, tota, ett, ett mä oon, mä oon niin ammattitaitonen noiss, itse siinä meiän substanssiss, mull on niin vahva substanssiosaaminen ja sitte, sitt mä luulen, ett mull on just, ne vuorovaikutustaidot on niin ku mun vahvuuksia, että, ett mä osaan niin ku ne, sitt olla sillee sinne asiakkaille päin, ett ne, tai niin ku hoitaa niitä asioita niin ku hyvin. Ja mä 
oon saanu hyvää palautetta... Mä oon saanu esimieheltäni sellast, lähiesimiehelt, semmosta palautetta, että, että, tota, että sataprosenttinen luottamus siihen, että varmasti hoid, hoidan asiat ja että hän ei, hän ei tulis toimeen ilman minua ollenkaan, hän ois ihan niin nesteessä. [nauraa] Ja sitte asiakkaalta sitä, ett on ilo olla tekemisissä." (Kaarina)

Organisaationsa pitkäaikaisena työntekijänä Kaarina oli vahvin ehdokas tehtävään: hänellä oli sekä muodollinen pätevyys että alan vahva substanssiosaaminen ja hyvät sosiaaliset taidot. Häntä myös pidettiin luotettavana työntekijänä: "Muhun voi kyllä sataprosenttisesti luottaa. Mä teen työni ... niin hyvin, kun mä pystyn." Iän tuoma työkokemus näyttäytyi tilanteessa vahvuutena, ei heikkoutena (vrt. Irni 2010; Kelan 2008; Siivonen \& Isopahkala-Bouret 2016). Samaan tapaan myös Marjaana tuo esiin vahvan liiketoiminnallisen osaamisensa, joka oli kertynyt nimenomaan kokemuksen myötä.

"Kai sitä jollaki tavall noteerattiin [työnhaussa, että] mull oli niin vahva se liiketoiminnallinen tausta, se osaaminen työelämästä, ett mä pystyin pudottelemaan ne kaikki asiat, mitä mä [sen9 yliopiston jälkeen [muodollisesti olin opiskellut]... Mä pystyin kertomaan, miten tulosta parannetaan, miten henkilöstöä hoi[detaan]... mä pystyin niinku tavallaan, ett se oli mulla käytännön kokemuksena niin pitkällä, että mä oisin pystyny ilman [niitä maisterin] papereitakin... sen saman asian siis hoitamaan." (Marjaana)

Marjaana toi haastattelussa selkeästi esiin sen, että oli oppinut suurimman osan siitä, mihin yliopistotutkinto hänet pätevöitti, työuransa aikana ja nimenomaan työn kautta. Vahvaa ammatillista kokemusta ja työhistoriaa korostava puhetapa voidaankin nähdä yhtenä ikäneuvottelun välineenä. Molemmat naiset olivat päässeet asiantuntija- ja johtotason tehtäviin ja kokivat, että heidän työssään iän tuomaa kokemusta arvostettiin. Omien kykyjen ja ominaisuuksien korostaminen pyrkii samalla lisäämään ikääntyvien naisten arvostamista.

Jatkuvan itsensä kehittämisen korostaminen on tärkeä osa iästä käytäviä neuvotteluja. Elinikäinen oppiminen kietoutuu osaksi uudenlaisia ikääntymisen (tai iättömyyden) performansseja (Siivonen 2012; Isopahkala-Bouret 2015a). Naisten kerronta tarjoaa vaihtoehtoisen tavan lähestyä ikääntymistä ja haastaa ikästereotypioita, joissa ikä liitetään haluttomuuteen muuttua ja oppia uutta. Oppimismyönteinen puhe saattoi heijastella sitä, että itselle ja itsestä haluttiin antaa nuorekas ja helposti työllistettävä vaikutelma ikääntymisestä huolimatta (ks. Moreau \& Leathwood 2006).

"Että mull on niin ku, mull on niin ku asenne, jolla, jolla niin kun [keskipitkä tauko], mull on asenne oppimiseen niin ku kohdallaan... mä suhtaudun siihen niin ku [pieni tauko] myönteisesti ja se on hirveän tärkeä asia ja, että tota, elämä on niin ku oppimista niin ku koko ajan ja missään iäss, mi, millonkaan ei oo niin ku liian vanha varmaan oppimaan niin ku uutta." (Kaarina)

"Mä nautin opiskelusta. Se on oikeesti, ett mä nautin siitä. Musta on ihana tietää lisää, ja siis ymmärtää ja osata. Mä oon aina ollu semmonen." (Marjaana)

Elinikäisen oppimisen näkökulmasta korkeakoulutuksen merkitys ei siis rajoittunut tutkintoon ja muodollisen pätevyyden hankkimiseen. Opiskelu korkeakoulussa oli keino haastaa ikään liittyviä kielteisiä ikästereotypioita (liittyen mm. haluttomuuteen oppia ja kehittyä) ja hankkia tunnustusta omalle oppimiskyvylle ja osaamiselle (Isopahkala-Bouret 2015a; 2015b; Siivonen \& Isopahkala-Bouret 2016).

\section{POHDINTA}

Olemme tässä artikkelissa tarkastelleet viisikymppisenä korkeakoulututkinnon suorittaneiden Marjaanan ja Kaarinan haastatteluihin pohjautuvaa tapaustutkimusta. Naisia yhdisti paitsi korkeakoulututkinnon suorittaminen keski-iässä myös samankaltainen koulutushistoria sekä asema työelämän asiantuntija- ja johtotehtävissä. Analysoimme, millaisia merkityksiä viisikymppisenä valmistuneet naiset antoivat korkeakoulutukselle suhteessa ikääntymiseen ja vallitsevaan työllistettävyysdiskurssiin. 
Tutkintotavoitteista aikuisopiskelua yliopistossa kehysti vahvasti työllistettävyysdiskurssi ja kulttuuriset käytännöt, joiden mukaan asemaa ja arvostusta työelämän hierarkioissa määrittää koulutustausta (Brown, Hesketh \& Williams 2003). Kuten olemme aikaisemmassa tutkimuksessamme tuoneet esiin (Siivonen \& Isopahkala-Bouret 2016), ne joilla on hyvät työmarkkina-asemat jo ennen korkeakouluopintoja, ovat paremmassa asemassa etsiessään työtä valmistumisensa jälkeen - iästä riippumatta. Oman elämänsä yrittäjäksi tulemista ja valmiutta jatkuvaan oppimiseen ja kouluttautumiseen vaaditaan missä tahansa iässä, myös vanhemmilta työntekijöiltä, jotka haluavat satsata omaan työllistettävyyteensä ja pysyä aktiivisesti mukana työelämässä (Siivonen \& Isopahkala-Bouret 2016).

Marjaanan ja Kaarinan tapausta voisi tarkastelumme pohjalta kuvata menestystarinaksi. Iän tuoma kokemus saa heidän kohdallaan myönteisiä merkityksiä ja ikääntyminen materialisoituu resurssina työmarkkinoilla. Halu ja tarve jatkuvaan uuden oppimiseen niin työelämässä kuin muodollisessa koulutuksessakin määrittivät heidän koulutus- ja työelämäpolkujaan. Molemmat olivat saavuttaneet hyvän aseman työelämässä jo ennen keski-iässä suorittamaansa korkeakoulututkintoa. Vahvan työkokemuksen tuoma substanssiosaaminen ja korkeakoulutuksen formalisoima muodollinen pätevyys takasivat pääsyn asiantuntija- ja johtotehtäviin keski-iässä, jolloin naisten paras työelämäikä on jo keskimäärin ohi (Vaahtio 2003; Viitasalo 2013). Kaarina ja Marjaana kuuluvat ikänsä ja sukupuolensa puolesta ryhmään, jossa esiintyy Viitasalon (2015) mukaan yleisemmin ikäsyrjintää Suomessa. Kumpikaan naisista ei kuitenkaan kertonut varsinaisesti kokeneensa ikäsyrjintää työpaikallaan, pikemminkin he toivat esiin, että kokeneita työntekijöitä arvostettiin heidän organisaatioissaan.

Ikään liittyvät merkitykset kietoutuvat osaamiseen ja kykyihin, jotka on usein saavutettu jo aikaisempien opintojen ja työkokemuksen kautta, mutta jotka tulevat uudella tavalla formalisoitua keski-iässä suoritetulla muodollisella korkeakoulututkinnolla. Tuoreen korkeakoulututkinnon avulla ikääntyvien naisten on helpompi neuvotella työllistettävyydestä ja omasta asemasta työelämän hierarkioissa. Kuten Silvennoinen (2007) on tuonut esiin, matalasti koulutetut ikääntyneet joutuvat tekemään huomattavasti enemmän töitä määritelläkseen elämäänsä ja olemistaan työllistettävyysdiskurssin vaatimalla tavalla.

Marjaanan ja Kaarinan tapaus haastaa ikääntymiseen liitettyjä oletuksia työllistettävyyden heikkenemisestä, oppimisen hidastumisesta ja vaikeutumisesta sekä työmotivaation laskusta. Tuoreen tutkinnon suorittaminen ja uralla eteneminen haastavat länsimaissa vallalla olevaa luopumista ja luovuttamista korostavaa ikääntymisdiskurssia (Gullette 2003). Tässä tapauksessa on erityisen kiinnostavaa se, kuinka nimenomaan yksilöllisiä kykyjä korostavan työllistettävyysdiskurssin omaksuminen toimii ikästereotypioiden haastajana.

Yksilöllistä osaamista ja menestystä korostavan resistanssin voima on kuitenkin rajallinen, eikä se riitä haastamaan ikääntyvien naisten työllistettävyyden jännitteitä yhteiskunnallisella ja kollektiivisella tasolla. Menestystarinan ja vastakertomuksen lisäksi analyysimme toi esiin ikään ja sukupuoleen liittyvät neuvottelut omasta osaamisesta ja pätevyydestä suhteessa nuorempiin työntekijöihin esimerkiksi rekrytointitilanteessa. Iän, sukupuolen ja työllistettävyyden suhde on monimutkainen ja usein naisten työmarkkina-asemaa heikentävä. Korkeakoulutus antoi kuitenkin tapauksemme naisille erityisen resurssin, jonka avulla heillä oli paremmat mahdollisuudet osallistua asemaansa koskeviin neuvotteluihin.

Korkeakoulututkinnon viisikymppisenä suorittaneet naiset eivät ole mikään yhtenäinen ryhmä, eikä tämän tapaustutkimuksen tuloksia voi siinä mielessä yleistää. Kuitenkin se, minkälaisia neuvotteluja korkeakoulutuksen merkityksestä, ikääntymisestä ja työllistettävyydestä nousi tässä analyysissa esiin, kertoo laajemminkin yhteiskunnassamme vallitsevista ihanteista ja ikääntyvien asemasta. Kuten olemme aikaisemmassa tutkimuksessammekin (Siivonen \& Isopahkala-Bouret 2016) esittäneet, ikä voi suotuisaan diskursiiviseen kehykseen asetettuna toimia myös ikääntyvien naisten työllistettävyyttä vahvistavana tekijänä. 
Ulpukka Isopahkala-Bouret

$K T$, Aikuiskasvatustieteen dosentti, yliopistonlehtori

Käyttäytymistieteellinen tiedekunta

Käyttäytymistieteiden laitos

Helsingin yliopisto

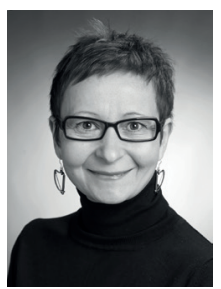

Päivi Siivonen

FT, yliopistotutkija

Filosofinen tiedekunta

Kasvatustieteiden ja psykologian

osasto

Itä-Suomen yliopisto

\section{LÄHTEET}

Andrews, M. (2004). Opening to the original contributions. Counter-narratives and the power to oppose. Teoksessa M. Bamberg \& M. Andrews (toim.) Considering counter-narratives: narrating, resisting, making sense. John Benjamins, 1-16.

Aro, M. (2014). Koulutusinflaatio. Koulutusekspansio ja koulutuksen arvo Suomessa 1970-2008. Turun yliopisto.

Boden, R. \& Nedeva M. (2010). Employing discourse: universities and graduate 'employability'. Journal of Education Policy, 25(1), 37-54.

Brennan, J., Mills, J. Shah, T. \& Woodley, A. (2000). Lifelong learning for employment and equity: The role of part-time degrees. Higher Education Quarterly, 54(4), 411-418.

Brown, P., Hesketh A. \& Williams S. (2003). Employability in knowledge-driven society. Journal of Education and Work. 16(2), 107-126.

Crompton, R. (2001). Gender, comparative research and biographical matching. European Societies. 3(2), 167-190.

Davies, B. \& Harré, R. (1990). Positioning: The discursive production of selves. Journal of the Theory of Social Behaviour 20(1), 43-63.

Eurostat (2015). People outside the labour market. http://ec.europa.eu/eurostat/statistics-explained/ index.php/People_outside_the_labour_market (Luettu 23.10.2015)

Gullette, M. (2003). From life storytelling to age autobiography. Journal of Aging Studies, 17(1), 101-111.

Hyvärinen, M. \& Löyttyniemi, V. (2005). Kerronnallinen haastattelu. Teoksessa J. Ruusuvuori \& L. Tiittula (toim.), Haastattelu. Tutkimus, tilanteet ja vuorovaikutus. Vastapaino, 189-222.

Irni, S. (2010). Ageing apparatuses at work. Transdisciplinary negotiations of sex, age and materiality. Åbo Academi University Press.

Isopahkala-Bouret, U. (2015a). Graduation at age 50+: Contested efforts to construct 'third age' identities and negotiate cultural age-stereotypes. Journal of Aging Studies 35, 1-9.

Isopahkala-Bouret, U. (2015b). Educational Credentialing of an Aging Workforce: Uneasy Conclusions. Adult Education Quarterly 65(2), 83-99.

Isopahkala-Bouret, U. (2016) 'It's a great benefit to have grey hair!' The intersection of gender, ageing and visibility in midlife professional women's narratives. Journal of Women and Aging. Published online before print: http://www.tandfonline.com/doi/abs/1 $0.1080 / 08952841.2016 .1142773$ ?journalCode=wj wa20

Jyrkinen, M. \& McKie, L. (2012). Gender, age and ageism: experiences of women managers in Finland and Scotland. Work, employment and society 26(1), 61-77.

Kelan, E. (2008). Gender, risk and employment insecurity: The masculine breadwinner subtext. Human Relations 61(9), 1171-1202.

Linde, C. (1993). Life stories: The creation of coherence. Oxford University Press.

Miller, P. \& Rose N. (2008). Governing the present. Polity Press.

Moore, E. (2003). Pitkä opintie. Aikuisiällä suoritettu yliopistotutkinto ja koulutuksellisen elämänkulun muutos. Joensuun yliopisto.

Moreau, M-P. \& Leathwood, C. (2006). Graduates' employment and the discourse of employability: a critical analysis. Journal of Education and Work 19(4), 305-324.

Mutanen, H. \& Siivonen, P. (2016). Narratiivinen positiointianalyysi ja nuorten aikuisten toimijuus työpajaympäristössä. Aikuiskasvatus 37(2), 84-98.

Ojala, H. (2010). Opiskelemassa tavallaan. Vanhat naiset ikäihmisten yliopistossa. Tampereen yliopisto.

Paloniemi, S. (2004). Ikä, kokemus ja osaaminen työelämässä. Työntekijöiden käsityksiä iän ja kokemuksen merkityksestä ammatillisessa osaamisessa ja sen kehittämisessä. Jyväskylän yliopisto. 
Phoenix, C., \& Smith, B. (2011). Telling a (good?) counter story of aging: Natural bodybuilding meets the narrative of decline. The Journals of Gerontology. Series B, Psychological Sciences and Social Sciences 66(5), 628-639.

Puhakka, A., Rautopuro, J. \& Tuominen, V. (2010). Employability and Finnish University Graduates. European Educational Research Journal 9(1), 45-55.

Puhakka, A., Rautopuro, J., Tuominen, V. \& VuorinenLampila, P. (2012). Current employability and graduate employment research in Finland. In Ahola S. \& Hoffman D. H. (toim.), Higher education research in Finland. Emerging structures and contemporary issues. University of Jyväskylä, 357-381.

Purcell, K., Wilton, N. \& Elias, P. (2007). Hard Lessons for Lifelong Learners? Age and Experience in the Graduate Labour Market. Higher Education Quarterly, 61(1), 57-82.

Pärnänen, A. (2011). Organisaatioiden ikäpolitiikat: strategiat, instituutiot ja moraali. Tilastokeskus.

Rinne, R. (1998). Akateemiset tutkinnot muuttuvana työmarkkinavaluuttana. Teoksessa M.-R. Järvinen, R. Rinne \& E. Lehtinen (toim.) Yliopistot ja muuttuvat työelämä. Turun yliopisto, 13-42.

Ruoholinna, T. (2009). Ikääntyvät työelämässä. Päihittääkö nuoruus ja koulutus aikuisuuden ja kokemuksen? Turun yliopisto.

Skeggs, B. (1997). Formations of Class and Gender: Becoming Respectable. SAGE.

Siivonen, P. (2012). Ikä ja koulutettavuuden dilemmat viisikymppisten ja kuusikymppisten naisten kerronnassa. Aikuiskasvatus 32(3), 190-200.

Siivonen, P. (2016). Becoming an educable lifelong learning subject. Adult graduates' transitions in education and working life. International Journal of Lifelong Education 35(1), 35-50.

Siivonen, P., Komulainen, K., Räty, H., Korhonen, M., Kasanen, K., \& Rautiainen, R. (2016). Salvation or a Broken Promise? Two adult graduates' social positioning in education and working life. Scandinavian Journal of Educational Research 60(1), 110-125.

Siivonen, P., \& Isopahkala-Bouret, U. (2016). Adult graduates' negotiations of age(ing) and employability. Journal of Education and Work 29(3), 352-372.

Silvennoinen, P. (2007). Ikä, identiteetti ja ohjaava koulutus: ikääntyvät pitkäaikaistyöttömät oppimisyhteiskunnan haasteena. Jyväskylän yliopisto.

Tomlinson, M. (2008). The degree is not enough: students' perceptions of the role of higher education credentials for graduate work and employability. British Journal of Sociology of Education 29(1), 49-61.
Vaahtio, E.-L. (2003). Työmarkkinaikää ei lasketa kalenterista. Tutkimus rekrytoinnista, iästä ja ageismista. Työpoliittinen aikakauskirja 2/2003. Työministeriö.

Viitasalo, N. (2013). Torjunnasta eristämiseen. Sosiaalisen syrjäyttämisen käytänteitä työssä. Janus 21(1), 4-21.

Viitasalo, N. (2015). Varttuneet ja ikäsyrjintä työelämässä. Tampereen yliopisto.

1 Isopahkala-Bouretin tutkimusprojektissa haastateltiin vuonna 2012-2013 14 (12 naista ja 2 miestä) kauppatieteiden tai sosiaalitieteiden maisterin tutkinnon viisikymppisinä suorittanutta henkilöä. Haastateltavat olivat haastatteluhetkellä 54-62-vuotiaita. He olivat työskennelleet monilla eri aloilla, kuten henkilöstöhallinnossa, johdon konsultoinnissa, viestinnässä, markkinoinnissa, sekä erilaisissa sosiaalityön tehtävissä. Ennestään heistä suurimmalla osalla oli 1970-luvulla tai 1980-luvun alussa suoritettu saman alan alempi korkeakoulututkinto tai toisen alan maisterin tutkinto. Neljä haastateltavista oli suorittanut alemman korkeakoulututkinnon vasta 2000-luvulla, ennen jatkamistaan maisteriopintoihin.

2 Siivosen tutkimusprojektissa haastateltiin kymmentä (7 naista ja 3 miestä) aikuislukion suorittanutta henkilöä ensimmäisen kerran vuosina 2004-2005 sekä uudelleen vuonna 2012. Haastateltavat olivat 32-56-vuotiaita toisen haastattelun aikana. He olivat kaikki haastatteluhetkellä työelämässä ja yhdeksän heistä oli pyrkinyt ja kahdeksan jatkanut opintojaan aikuislukiosta valmistumisen jälkeen. Kaksi opiskelijaa oli valmistunut ammattikorkeakoulusta, yksi yliopistosta ja yksi ammatillisesta koulutuksesta. Neljä jatkoi tai suunnitteli jatkavansa opintojaan. Neljällä oli ennen aikuislukiota suoritettu ammatillinen tutkinto. 